\title{
Educaţia ca valoare şi fundament al consilierii adolescenţilor şi familiei acestora în instituţia de învăţământ
}

\author{
Zinaida MICLEUȘANU*
}

Abstract: Education as the value and foundation of the adolescents and their family consultation in the educational institute. Family education and the training of younger generations, through family counseling within the school, are valuable and become an indispensable necessity in the process of strengthening and harmonizing family relationships. Thus, the school has a new function, the remediation and support of the family, the realization of effective family education, adjustment to the problems and demands of the social integration of the young generation. This objective aims at supporting and counseling not only the student but also the family within the educational institution. Collaboration of educational agents through the counseling of the pupil and his / her family is a current priority aimed at making the best possible use of the family to optimize the child's education and to strengthen family relationships. Children's education includes not only their training, but also their counseling to learn effectively and sustainably, thus providing conditions conducive to the harmonious formation and development of personality.

Keywords: family, adolescence, family education, counseling, children's education.

Educaţia familială, cât şi instruirea tinerii generaţii, realizate prin intermediul consilierii familiei în cadrul şcolar, constituie o valoare şi devine o necesitate indispensabilă în procesul fortificării

* Lect univ. dr., Facultatea de Psihologie și Asistență Socială, Universitatea de Studii Europene din Republica Moldova. 
şi armonizării relaţiilor familiale. Astfel şcoala în ultimele decenii s-a văzut nevoită să actualizeze mult mai insistent şi calitativ funcţia de remediere, dezvoltare şi susţinere a familiei, să revadă conţinutul, formele şi metodele de cultivare a competenţelor parentale, activizând colaborarea şi parteneriatul educaţional elevi cadre didactice - părinţi/ şcoală - familie. Acest obiectiv vizează susţinerea şi consilierea nu numai a elevului, ci şi a familiei în cadrul instituţiei de învăţământ. Colaborarea agenţilor educativi prin activitatea de consiliere a elevului şi familiei acestuia, reprezintă o prioritate actuală orientată spre valorizarea la maximum a familiei pentru optimizarea educaţiei copilului, dar şi a consolidării relaţiiilor familiale copii-părinţi. Educaţia copiilor include nu doar instruirea acestora, ci şi consilierea lor pentru a învăţa eficient şi durabil, asigurându-le astfel condiţii favorabile formării şi dezvoltării armonioase a personalităţii ${ }^{1}$.

În studiul dat reflectăm aspectele de bază ale consilierii elevului în instituţia de învăţământ. Consilierea elevului şi a familiei acestuia reprezintă un proces complex, o activitate structurată în trei etape:

- Etapa iniţială în consiliere, presupune stabilirea unei relaţii efective între consilier şi elev. Această etapă este decisivă în procesul de consiliere, deoarece stabilirea unei relaţii bazate pe acceptare, încredere şi colaborare, favorizează producerea schimbărilor pozitive în comportamentul adolescentului. Formularea scopurilor, a obiectivelor şi determinarea paşilor care vor urma, se face împreună cu beneficiarul, adică cu adolescentul. La fel, se discută schimbările comportamentale, rezultatele aşteptate. Dezvoltarea abilităţilor de luare a deciziei şi eliminare a gândurilor negative este, de asemenea, un pas care trebuie realizat chiar la început.

- Etapa fundamentală a consilierii are ca scop asistarea şi susţinerea adolescentului pentru a-l ajuta să-şi dezvolte interesele personale şi sociale; să-şi formeze şi perfecţioneze competenţele de relaţionare, cooperare şi comunicare $\mathrm{cu}$

${ }^{1}$ Larisa CuZneţov, Consilierea parentală, Chişinău, Edit. Primex-Com SRL, 2013, p. 19. 
Educaţia ca valoare şi fundament al consilierii adolescenţilor şi familiei acestora în instituţia de învăţământ

ceilalţi. Se va pune accent pe ajutorul oferit elevului, ca acesta să se cunoască şi să se autoevalueze. Se va asigura atmosfera caldă şi empatia, fără să fie excluse observaţia beneficiarului, analiza, interpretările, sumarizările, resemnificarea şi confruntarea constructivă. Totodată, utilizarea sugestiei, convingerii, metaforei, elementelor de artterapie şi ludoterapie pot fi de un real folos pentru elev.

- $\quad$ Etapa finală a consilierii pune accentul pe încheierea muncii în comun, fiind orientată spre elaborarea unor strategii, acte şi comportamente constructive. Vor fi învăţate proceduri specifice, dezvoltate planuri de acţiune, începând cu cele mai simple şi până la cele mai complicate în vederea adoptării unui nou comportament. În această etapă pot fi analizate schimbările care au intervenit în viaţa elevului; pot fi stabilite anumite sarcini şi se discută ce strategii va aplica adolescentul în viitor, pentru a-şi dezvolta independent anumite cogniţii, atitudini şi comportamente.

Specificul consilierii psihopedagogice a copiilor reiese din particularităţile de vârstă a acestora. Aceştia sunt în plin proces de formare a personalităţii, parcurg anumite perioade de creştere şi se confruntă cu unele crize (de exemplu, criza de detaşare de familie); au probleme de autocontrol comportamental şi de adaptare la noile cerinţe, norme şi reguli în liceu. Pornind de la aceste realităţi, consilierii trebuie să posede şi competenţe specifice ca:

- capacitatea de a stabili relaţii adecvate cu elevul şi părinţii;

- capacitatea de observare atentă a copilului şi ascultarea lui activă;

- atragerea elevului în variate activităţi speciale, inclusiv prin utilizarea artei, sportului, jocului, exerciţiului structurat, valorificându-le ca modalităţi de educaţie, corecţie şi de schimbare evolutivă;

- încurajarea elevului pentru a-şi exprima obiectiv şi sincer gândurile şi emoţiile ${ }^{2}$.

${ }^{2}$ IDEM, Consilierea parentală, Chişinău, Edit. Primex-Com SRL, 2013, p. 20. 
Din perspectiva, teoriilor ce ţin de psihologia dezvoltării, elevii cu vârsta cuprinsă între 16 şi 20 ani se înglobează în etapa de vârsta adolescentină. Consilierul care are misiunea de a consilia adolescenţii, trebuie să posede o pregătire vastă în domeniul psihologiei vârstelor şi pedagogiei, să înţeleagă elevul, să corespundă comportamentului şi aşteptărilor acestuia. Numai o personalitate integră, realistă, autentică, stabilă şi consecventă este în stare să consolideze şi să menţină încrederea copilului, mai cu seamă la vârsta adolescenţei. Elevul va percepe relaţia cu consilierul ca fiind una empatică, bazată pe încredere. Totodată, trebuie să conştientizăm că, lumea adultului este foarte diferită de cea a copilului. De aceea pentru a atinge scopul dorit, consilierul trebuie să menţină legătura internă cu eul său de copil - ca componentă a personalităţii sale. Această legătură cu eul său de copil nu presupune transformarea comportamentului consilierului într-un comportament copilăros, ci presupune transpunerea sa în lumea copilului. Doar aşa consilierul, lucrând cu elevii va avea şanse mai mari să menţină relaţii eficiente cu beneficiarii; va reuşi să perceapă sentimentele şi percepţiile copilului, minimalizând posibilitatea de a reprima sentimentele acestuia. Emoţiile şi gândurile nedezvăluite şi nepercepute de consilier, ar putea avea urmări nedorite asupra copilului, care ar provoca fobii şi nevroze pe viitor. De obicei, beneficiarii, inclusiv copiii vor să evite sentimentele şi emoţiile nepăcute. Pentru ei, ca şi pentru adulţi, trăirea sentimentelor neplăcute, pot genera grave dereglări comportamentale $(8 ; 9 ; 12 ; 17)$.

Pentru a face faţă şi a derula activitatea de consiliere a adolescenţilor eficient atât diriginţii, pedagogii cât şi managerii şcolari trebuie să cunoască foarte bine particularităţile de vârstă. În acest context realizăm o succintă incursiune în descrierea trăsăturilor de bază a adolescenţei.

Cercetătorii Buchanan C. M., Eccles J. S., Becker J. B. ${ }^{3}$ caracterizează vârsta adolescenţei din perspectiva factorilor biologici, psihologici şi sociali, concomitent analizând influenţa hormonilor

${ }^{3}$ R. Adams Gerald, Michael D. Berzonsky, Psihologia adolescenţei, Iaşi, Edit. Polirom, 2009, p. 28. 
asupra trăsăturilor şi comportamentului adolescenţilor. Să nu uităm că schimbările hormonale produse la nivelul fiziologic al adolescenţilor pot influenţa stima de sine, emoţiile, capacităţile de concentrare, relaţionarea cu semenii, comportamentul în familie şi şcoală etc. Uneori aceste schimbări biologice îi determină pe adolescenţi să fie încăţăîţinaşi, rebeli, chiar violenţi. În general, vârsta adolescenţei constituie una dintre cele mai fascinante şi mai complexe tranziţii din decursul vieţii omului, dat, totodată, este şi o vârstă a căutărilor active, a determinării identităţii sale, a rostului în viaţă, a experimentelor sociale. Carnegie D. în lucrarea Council on Adolescent Development (1996) remarcă un aspect important (după stadiul sugarului), adolescenţa este cea mai rapidă perioadă de creştere şi schimbare psihofizică. La sfârşitul pubertăţii, majoritatea copiilor s-au confruntat deja cu schimbări hormonale, au dobândit caractere sexuale secundare şi au acumulat în greutate şi în înălţime. Aceste schimbări produc obţinerea unui organism matur, cu capacităţi fizice şi reproductive, precum şi cu un aspect exterior pe măsură. Este un fapt unanim recunoscut că adolescenţii se confruntă cu numeroase provocări sociale şi emoţionale atunci când traversează faza dintre copilărie şi maturitate ${ }^{4}$. Schimbările fizice în perioada adolescenţei sunt radicale şi, în plus, imprevizibile, în sensul că rezultatul specific final al acestora este necunoscut. Impactul psihologic, pe lângă schimbările hormonale asociate adolescenţei, a reprezentat un domeniu de interes în studiul dezvoltării adolescentului ${ }^{5}$. Adolescenţa este o perioadă cu multe probleme de adaptare la realitate. Criza de identitate, nonconformismul şi într-o anumită măsură, teribilismul adolescenţilor, constituie probleme de care comunitatea trebuie să ţină cont dacă doreşte să funcţioneze adecvat. Problemele adolescenţilor sunt şi problemele familiei, chiar a întregii comunităţi în care aceştia trăiesc. Astfel, consilierea adolescenţilor, în primul rând are ca scop pregătirea adolescentului pentru integrarea optimă în viaţa socială, în profesie etc. ${ }^{6}$. Consilierul, care are misiunea de a consilia adolescenţii, trebuie să posede o pregătire vastă în domeniul psihologiei vârstelor şi

\footnotetext{
${ }^{4}$ Ibidem, p. 46-47.

5 Ibidem, p. 57.

${ }^{6}$ Ion Al. Dumitru, Consiliere psihopedagogică, Iaşi, Edit. Polirom, 2008, p. 100.
} 
pedagogiei, să înţeleagă elevul, să corespundă comportamentului şi aşteptărilor acestuia. Numai o personalitate integră, realistă, autentică, stabilă şi consecventă este în stare să consolideze şi să menţină încrederea copilului, mai cu seamă la vârsta adolescenţei. Elevul va percepe relaţia cu consilierul ca fiind una empatică, bazată pe încredere.

Coraportând cele expuse anterior, apare necesitatea de a delimita dificultăţile psihoemoţionale şi comportamentale, cu care se confruntă adolescenţii (care au un impact nefavorabil asupra reglării conduitei acestora la general), dar şi modalităţile de soluţionare a lor, în procesul consilierii psihopedagogice. Dificultăţile vizate au fost stabilite în urma unor cercetări de durată (4 ani).

\begin{tabular}{|c|c|c|}
\hline $\begin{array}{l}\text { Nr. } \\
\text { d/o }\end{array}$ & $\begin{array}{c}\text { Dificultăţile cu care } \\
\text { se confruntă } \\
\text { adolescenţii }\end{array}$ & $\begin{array}{l}\text { Modalităţile recomandabile de } \\
\text { soluţionare a problemei }\end{array}$ \\
\hline 1 & 2 & 3 \\
\hline I & \multicolumn{2}{|c|}{ În mediul familial } \\
\hline & $\begin{array}{c}\text { • Relaţionarea } \\
\text { defectuoasă cu } \\
\text { părinţii. } \\
\text { • Comunicarea } \\
\text { distorsionată cu } \\
\text { membrii familiei. } \\
\text { - Regulile stricte ale } \\
\text { părinţilor. } \\
\text { - Monitorizarea/ } \\
\text { supravegherea/ } \\
\text { controlul psihologic } \\
\text { exagerat din partea } \\
\text { părinţilor. } \\
\text { - Rivalitatea fraternă. }\end{array}$ & $\begin{array}{l}\text { - Consilierea psihopedagogică a } \\
\text { adolescentului. } \\
\text { - Consilierea psihopedagogică a } \\
\text { părinţilor. } \\
\text { • Consilierea psihopedagogică a } \\
\text { fraţilor şi a familiei extinse (la } \\
\text { necesitate). } \\
\text { - Includerea adolescenţilor într-un } \\
\text { program de remediere care ar viza: } \\
\text { analiza conduitelor adecvate în } \\
\text { cadrul familial. } \\
\text { • Includerea adolescenţilor şi a } \\
\text { părinţilor lor într-un program de } \\
\text { remediere care ar viza: }\end{array}$ \\
\hline
\end{tabular}


Educaţia ca valoare şi fundament al consilierii adolescenţilor şi familiei acestora în instituţia de invățământ

\begin{tabular}{|c|c|c|}
\hline & $\begin{array}{c}\text { • Fuga de acasă, } \\
\text { vagabondajul. } \\
\text { • Violenţa familială. }\end{array}$ & $\begin{array}{c}\text { familiarizarea în detalii a } \\
\text { specificului vârstei adolescente şi } \\
\text { comportamentului lor. } \\
\text { • Psihologul în parteneriat cu } \\
\text { adolescentul şi familia sa, să } \\
\text { stabilească reguli de comportament/ } \\
\text { de comunicare non-abuzive, care ar } \\
\text { favoriza remedierea conflictelor } \\
\text { familiale şi armonizarea relaţiilor } \\
\text { familiale. } \\
\text { • Monitorizarea cazului şi, la } \\
\text { necesitate, realizarea consilierii şi } \\
\text { remedierii repetate. }\end{array}$ \\
\hline II. & \multicolumn{2}{|c|}{ În mediul şcolar } \\
\hline & $\begin{array}{l}\text { • Examenele / } \\
\text { testările dificile. } \\
\text { • Conflictele cu } \\
\text { colegii de clasă. } \\
\text { • Conflictele cu } \\
\text { cadrele didactice. } \\
\text { • Statutul } \\
\text { adolescentului în } \\
\text { cadrul colectivului de } \\
\text { elevi. } \\
\text { - Abandonul şcolar. } \\
\text { Violenţa şcolară. }\end{array}$ & $\begin{array}{c}\text { • Consilierea psihopedagogică a } \\
\text { adolescentului. } \\
\text { • Consilirea psihopedagogică a } \\
\text { cadrelor didactice. } \\
\text { • Consilierea psihopedagogică a } \\
\text { grupului de elevi, în care este inclus } \\
\text { adolescentul cu problemă. } \\
\text { • Diagnosticarea relaţiilor din } \\
\text { grupul de elevi în care este inclus } \\
\text { adolescentul cu problemă - ex: } \\
\text { Testarea Sociometrică. } \\
\text { • Organizarea orelor educative } \\
\text { pentru adolescentul cu problemă şi } \\
\text { colegii săi cu genericul (consilierea } \\
\text { pentru dezvoltare): } \\
\text { - Comunicarea cu semenii; }\end{array}$ \\
\hline
\end{tabular}




\begin{tabular}{|c|c|c|}
\hline & & $\begin{array}{c}\text { - Comportamentul prosocial; } \\
\text { - Violenţa ca fenomen - prevenire } \\
\text { şi diminuare. } \\
\text { - Modul sănătos de vaţă etc. } \\
\text { - Realizarea meselor rotunde } \\
\text { consultative pentru cadrele } \\
\text { didactice cu tematica: a. strategii de } \\
\text { îmbunătăţire a coeziunii în grupul } \\
\text { de elevi; b. dozarea raţională a } \\
\text { temelor pentru acasă etc. } \\
\text { - Includerea adolescenţilor şi a } \\
\text { cadrelor didactice într-un program } \\
\text { de remediere cu scopul remedierii/ } \\
\text { prevenirii conflictelor apărute în } \\
\text { procesul instructiv - educativ. } \\
\text { Psihologul în parteneriat cu } \\
\text { adolescentul şi cadrul didactic, să } \\
\text { întocmească un şir de reguli de } \\
\text { comportament şcolar. } \\
\text { Monitorizarea respectării regulilor } \\
\text { de comportament şcolar, dar dar şi } \\
\text { a cazurilor problemă, întru } \\
\text { soluţionarea eficientă şi prevenirea } \\
\text { lor şi, la necesitate, realizarea } \\
\text { consilierii şi remedierii repetate. }\end{array}$ \\
\hline II. & \multicolumn{2}{|c|}{ În mediul social (în general) } \\
\hline & $\begin{array}{c}\text { - Comunicarea cu } \\
\text { prietenii. } \\
\text { - Grupul de prieteni - } \\
\text { de apartenenţă a } \\
\text { adolescentului. }\end{array}$ & $\begin{array}{l}\text { - Consilierea psihopedagogică a } \\
\text { adolescentului. } \\
\text { - Consilierea psihopedagogică a } \\
\text { prietenilor adolescentului. }\end{array}$ \\
\hline
\end{tabular}


Educaţia ca valoare şi fundament al consilierii adolescenţilor şi familiei acestora în instituţia de învăţământ

\begin{tabular}{|c|c|}
\hline $\begin{array}{c}\text { • Devianţa } \\
\text { comportamentală. } \\
\text { • Conflicte/ } \\
\text { despărţirea de } \\
\text { persoana iubită. } \\
\text { - Consumul de tutun/ } \\
\text { alcool/ droguri. } \\
\text { • Intreţinerea } \\
\text { timpurie a relaţiilor } \\
\text { sexuale. } \\
\text { • Metodele de } \\
\text { contracepţie. } \\
\text { - Sănătatea (bolile } \\
\text { sexual transmisibile/ } \\
\text { schimbările } \\
\text { fiziologice din } \\
\text { organism). } \\
\text { - Sarcinile timpurii. }\end{array}$ & $\begin{array}{l}\text { • Consilierea psihopedagogică a } \\
\text { iubitului/ iubitei adolescentului/ } \\
\text { adolescentei. } \\
\text { - Organizarea orelor educative, } \\
\text { ateliere de consiliere etc. pe } \\
\text { tematici specifice problemei: } \\
\text { - Comunicarea cu prietenii, rudele; } \\
\text { - Modul sănătos de viaţă; } \\
\text { - Schimbările fiziologice din } \\
\text { organismul preadolescentului/ } \\
\text { adolescentului; } \\
\text { - Viaţa sexuală - momentul oportun } \\
\text { pentru primul act sexual, } \\
\text { contracepţie, sănătate sexuală; } \\
\text { - Bolile sexual transmisibile; } \\
\text { - Abstinenţa sexuală etc. } \\
\text { • Psihologul în parteneriat cu } \\
\text { adolescentul, să întocmească un şir } \\
\text { de reguli de comportament moral în } \\
\text { cadrul societăţii şi în cadrul } \\
\text { diverselor grupuri sociale. } \\
\text { - Monitorizarea respectării regulilor } \\
\text { de comportament social, dar şi a } \\
\text { cazurilor problemă, întru } \\
\text { soluţionarea eficientă şi prevenirea } \\
\text { lor şi, la necesitate, realizarea } \\
\text { consilierii şi remedierii repetate. }\end{array}$ \\
\hline
\end{tabular}

Tabel 1. Problemele psihoemoţionale şi comportamentale ale adolescenţilor şi modalităţile recomandabile de soluţionare a lor

Evident că problemele adolescentului provoacă dificultăţi educative, de comunicare şi relaţionare cu părinţii şi semenii 
acestora, ceea ce, la fel, necesită atenţie din partea pedagogilor, diriginţilor, serviciului psihologic şcolar.

Analizând problemele adolescenţilor şi modalităţile de soluţionare a lor, putem conchide că conflictul dintre generaţii trebuie transformat într-un dialog fructuos al acestora în interesul familiei, şcolii şi comunităţii, inclusiv, al fiecărui individ în parte, fie el adolescent, tânăr sau matur. Astfel, apare necesitatea de a cultiva adolescentului deprinderea de a apela la consilierea psihopedagogică, realizată de specialist psiholog/ cadru didactic, întru prevenirea şi soluţionarea eficientă a problemelor inevitabile din viaţa lor. În acest context, consilierea preventivă constituie tipul de consiliere menită să preîntâmpine apariţia unor probleme sau situaţii critice în viaţa adolescenţilor şi a familiei acestora.

Consilierea cu rol de prevenţie include activităţi educaţional - formative realizate cu grupurile de beneficiari (clase de elevi, grupuri de studenţi, grupuri de adulţi etc.) şi, uneori se realizează şi individual. Psihologul Dumitru I. Al., remarcă că prevenirea se focalizează pe acţiunea de îmbinare a două categorii de factori:

Factori de protecţie - cei care asigură potenţarea manifestării capacităţilor persoanei şi contribuie la menţinerea unui confort psihologic necesar dezvoltării optime a personalităţii sale. Factorii de protecţie ai adolescenţilor se referă la: existenţa unei familii care să susţină adolescentul şi săi asigure confortul fizic şi psihic optim; o dezvoltare fizică şi stare de sănătate bune; achiziţionarea unui set de deprinderi şi abilităţi educaţionale (de învăţare, de relaţionare, de autocontrol etc.); existenţa unui grup de referinţă/ de prieteni acceptaţi (şi) de părinţi; relaţii pozitive cu adulţi responsabili, afectuoşi şi de succes etc. Interacţiuea acestor factori şi dirijarea lor eficientă de către adulţi asigură o bună protecţie adolescenţilor, contribuind la prevenirea unor disfuncţionalităţi şi dezechilibre în dezvoltarea personalităţii lor, concretizate în comportamente dezadaptative, indezirabile şi chiar deviante ${ }^{7}$.

\footnotetext{
${ }^{7}$ Ibidem, p. 102-103.
} 
Educaţia ca valoare şi fundament al consilierii adolescenţilor şi familiei acestora în instituţia de învăţământ

Factori de risc - cu o probabilitate de manifestare relativ mare şi a căror acţiune poate genera disfuncţii majore la nivelul personalităţii şi al comportamentului adolescentului.

Factorii de risc ce se referă la viaţa adolescenţilor conduc la eventuale deficite de dezvoltare optimă a personalităţii. În această categorie sunt incluşi următorii factori:

- disfuncţii familiale (conflicte, violenţe, divorţ etc.);

- supravegherea neadecvată de către părinţi;

- sărăcia sau resursele materiale şi financiare precare;

- eventuale boli (mintale) ale părinţilor şi/ sau comportamentele neadecvate ale acestora (alcoolism, consum de droguri etc.);

- mediu extraşcolar vicios (pericole, violenţă, devieri cimportamentale etc.);

- probleme şi dificultăţi de învăţare;

- respingere din partea colegilor, izolare;

- consumul de alcool, tutun şi chiar droguri;

- părăsirea domiciliului şi, eventual, abandonul şcolar;

- promiscuitatea sexuală (prostituţie, viol, incest etc.);

- delicvenţa juvenilă.

În anasamblu, consilierea preventivă a adolescenţilor şi a familiei acestora, presupune potenţarea factorilor generali de protecţie şi estompare, până la anularea acţiunii, a factorilor generali de risc care influenţează viaţa şi activitatea adolescenţilor. În acest sens, consilierea preventivă este, în esenţă, o educaţie cu valenţe formative. Ea este menită să ajute şi să sprijine activitatea educatorilor, a cadrelor didactice şi a părinţilor pentru a realiza dezvoltarea optimă, la un nivel de calitate şi eficienţă sporite a adolescenţilor ${ }^{8}$.

Consilierea psihopedagogică a adolescenţilor este necesară pe tot parcursul modificărilor lor psihofiziologice şi a evenimentelor persistente în viaţa lor. Ea urmăreşte atingerea obiectivului specific major al consilierii adolescenţilor: orientarea şi oferirea sprijinului adolescentului pe parcursul dezvoltării sale şi

${ }^{8}$ Ibidem. 
a consolidării personalităţii lui. În consens cu specificul consilierii preventive şi pentru dezvoltare şi în legătură cu faptul că hotarele vârstelor sunt deseori confuze din cauza dezvoltării şi maturizării neuniforme/ prin salturi a individului, inclusiv, din considerentele necesităţii de analiză în ontogeneză a elevului am elaborat, în viziunea noastră, unul din cele mai importante instrumente cu caracter psihopedagogic (fără de care metoda biografică/ anamneza nu poate fi eficient realizată în cadrul consilierii elevului şi familiei lui). Acest instrument a fost numit de noi - Harta dezvoltării ontogenetice a familiei şi copilului (Figura 1).

\section{CONSILIEREA FAMILIEI}

\section{Componenta I:}

Starea şi dezvoltarea familiei

- condiţiile creării familiei

- structura familiei:

- părinţii

- fraţi/surori

- alte rude

- îndeplinirea funcţiilor (biologică, economică, educativă, psihologică, culturală, socială)

- modul de viaţă/stilul (sănătos; centrat pe valorile morale; dezechilibrat (în ce măsură etc.)

-calitatea comunicării şi relaţionării familiale (între soţi/părinţi şi copii-părinţi)

\section{Componenta II: Starea şi} dezvoltarea copilului

- decurgerea perioadei de pruncie (0-1 an)

- decurgerea perioadei timpurii (1-3 ani):

- crizele de la 1 an şi 3 ani

- decurgerea perioadei preşcolare:

- dezvoltarea senzitivoperceptivă

- formarea reprezentărilor

- dezvoltarea proceselor psihice cognitive: memorie, gândire, limbaj, imaginaţie etc.

- dezvoltarea afectivmotivaţională

- decurgerea dezvoltării copilului la vârsta şcolară mică: 
Educaţia ca valoare şi fundament al consilierii adolescenţilor şi familiei acestora în instituţia de învăţământ

- stilul educativ familial

(sistemul de cerinţe înaintat faţă de copil)

- modalitatea de relaţionare cu rudele apropiate (bunici, unchi, mătuşe etc.)

- valorile familiale şi calitatea mediului familiali

- cultura/ethosul general şi cel pedagogic al familiei

- sfera profesională a adulţilor

- sfera intereselor - hobby familial

- modalitatea de odihnă a familiei

- calitatea elaborării cu instituţia de învăţământ

- modalităţi de depăşire a dificultăţilor familiale
- pregătirea psihologică pentru instruirea şcolară/ criza de la 7 ani

- maturizarea psihofizică şi intelectuală

- maturizarea morală şi volitivă

- maturizarea socială

- dezvoltarea caracterului (trăsături pozitive şi negative (bunătatea, interes şi dragoste pentru cunoaştere; sinceritatea etc. trăsături negative: impulsivitatea, încăpăţinarea, capricios, dezvoltarea insuficientă a voinţei etc.)

- decurgerea dezvoltării preadolescentului:

- restructurările anatomiofiziologice şi psihosociale (maturizarea sexuală, ritmul de creştere; dezvoltarea sferei cognitive etc.)

- dezvoltarea neoformaţiunilor: a conştiinţei de sine; simţul autocunoaşterii;

- comunicarea şi relaţiile cu semenii

- conduita în cadrul familial şi şcolar

- decurgerea dezvoltării psihofizice şi sociale ale adolescentului:

- manifestarea crizei 


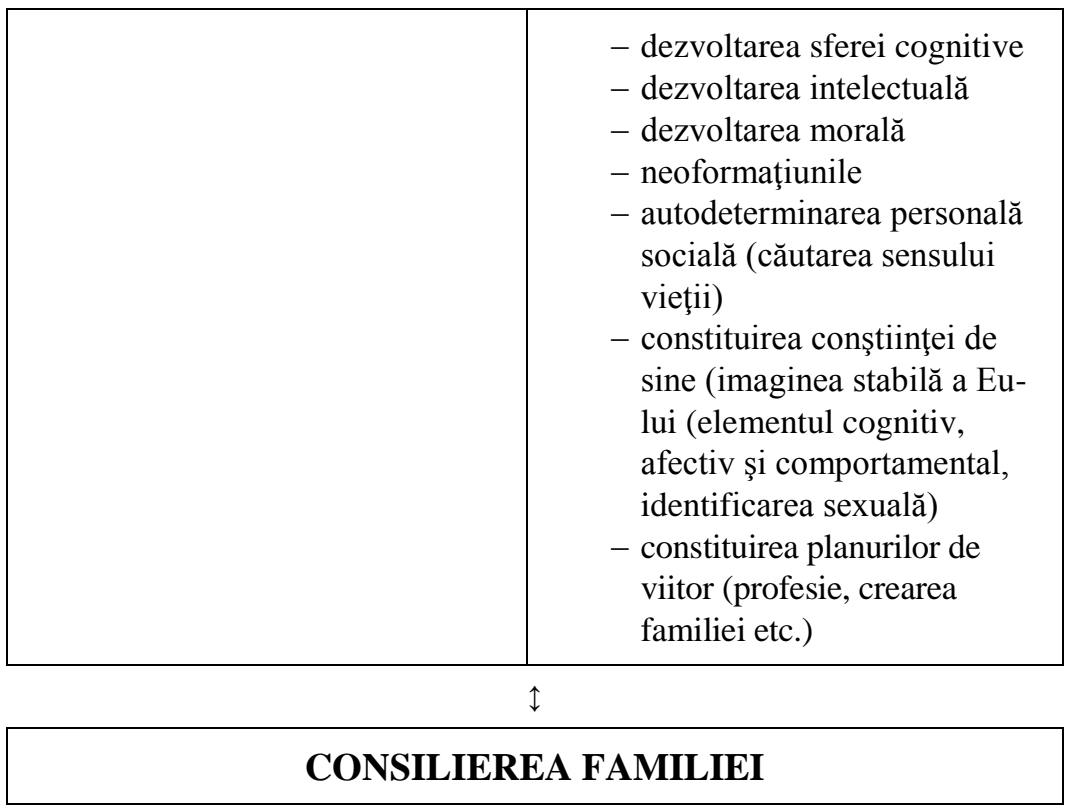

Fig. 1. Harta dezvoltării ontogenetice a familiei şi copilului

După cum putem observa, instrumentul dat (Figura 1) va asigura orientarea consilierului în culegerea şi valorificarea informaţiei despre copil/ adolescent şi familie, ceea ce va permite ulterior identificarea şi selectarea mai lesne a formelor, strategiilor şi metodelor/ tehnicilor pentru a realiza o consiliere eficientă (atât a elevului cât şi a familiei), căci consilierea psihopedagogică a copiilor şi a membrilor familiei vizează un set de acţiuni psihopedagogice sistematice şi sistemice, realizate prin intermediul formelor, metodelor şi strategiilor de identificare, remediere şi prevenire a discordanţelor şi incertitudinilor familiale.

În concluzie, menţionăm că, consilierea psihopedagogică realizată în cadrul instituţiei de învăţământ are la bază un sistem teoretic conceptual bine pus la punct. Ea este exercitată de către consilierul şcolar, psihologul, psihopedagogul, dirigintele sau cadrul didactic. Persoana care consiliază trebuie să posede competenţe de 
Educaţia ca valoare şi fundament al consilierii adolescenţilor şi familiei acestora în instituţia de învăţământ

valorificare a metodelor şi tehnicilor în corespundere cu problema identificată a elevului. Specialistul - consilier are menirea de a-l ajuta pe elev să se cunoască mai bine, să privească problemele obiectiv, dintr-o nouă perspectivă şi să-şi proiecteze un plan de soluţionare eficienta a problemlor cu care se confruntă. $\mathrm{O}$ condiţie importantă a consilierii psihopedagogice este caracterizată prin faptul că specialistul nu propune reţete sau soluţii prefabricate, ci orientează, apoi ghidează elevul/ grupul de elevi, consiliat spre luarea unei decizii optime pentru soluţionarea, de sine stătătoare, a problemei.

$\cos 80$

\section{Bibliografie}

1. AdAms Gerald, R., BERZONSKY, Michael D., Psihologia adolescenţei, Iaşi, Edit. Polirom, 2009.

2. AlbU, Gabriel, În căutarea educaţiei autentice, Iaşi, Edit. Polirom, 2002.

3. AtTILA, Vandra, Cum să ne educăm copiii, Ghid pentru părinţi în exerciţiu, București, Edit. Teora, 2008.

4. BĂBAN, Adriana, Consiliere educaţională. Ghid metodologic pentru orele de dirigenţie şi consiliere, Cluj-Napoca, Edit. Ardealului, 2009.

5. BIRCH, A., Psihologia dezvoltării, Bucureşti, Edit. Tehnică, 2000.

6. BONCHIŞ, Elena, Familia şi rolul ei în educarea copilului, Iaşi, Edit. Polirom, 2011.

7. CALARAŞ, Carolina, Consilierea educaţională realizată de diriginte în situaţii de criză ca element al culturii pedagogice, Chişinău, Vol. 1, 2009.

8. CARABET, Natalia, Consilierea familiei, Chişinău, CET „Ion Creangă", 2009.

9. CARON, Gerard, Cum să susţinem copilul în funcţie de temperamentul său: la şcoală şi acasăa, București, Didactica Publishing House, 2009.

10. Cuznețov, Larisa, Consilierea parentală, Chişinău, Edit. PrimexCom SRL, 2013.

11. IDEM, Consilierea şi educaţia familiei. Introducere în consilierea ontologică complexă a familiei, Edit. Chişinău, Primex-Com SRL, 2015. 
12. IDEM, Dimensiuni psihopedagogice şi etice ale parteneriatului educaţional, Chişinău, U. P. S. „I. Creangă”, 2002.

13. DIMITRIU-TIRON, Elena, Consiliere educaţională, Iaşi, Edit. Institutul European, 2005.

14. DRAGU, A. (coord.), Consilierea şcolară între provocări şi paradigme, volum cu lucrările primei conferinţe naţionale a psihologilor şcolari, Constanţa, Edit. NewLine, 2009.

15. DUMESNIL, Francois, Tot ce trebuie să ştie părinţii, Iaşi, Edit. Polirom, 2010.

16. DuMITRU, Ion Al., Consiliere psihopedagogică, Iaşi, Edit. Polirom, 2008.

17. GHERGUT, A., Evaluare şi intervenţie psihoeducaţională. Terapii educaţionale, recuperatorii şi compensatorii, Iaşi, Edit. Polirom, 2011.

18. Golu, P., Zlate, M., Verza, E., Psihologia copilului, Bucureşti, E. D. P., 1995.

19. MoRARU, Monica, Consiliere psihopedagogică şi orientare şcolară şi profesională, Constanţa, Edit. Muntenia CTA, 2004.

20. Nelson-Jones, R., Manual de consiliere, București, Edit. Trei, 2009.

21. Nemțeanu, C., Consideraţii despre consilierea psihologică, Bucureşti, Edit. Gnosis, 2004. 